\title{
The Global Economic Crisis And Retailers' Security Concerns: The Trends
}

\author{
https://doi.org/10.21272/sec.3(2).5-14.2019
}

\author{
Ayse Nilgun Balas, $\mathrm{PhD}$
}

Associate Professor of Marketing, Department of Management and Marketing, Virginia State University, USA

\author{
Halil Dincer Kaya, PhD \\ Professor of Finance, Department of Accounting and Finance, Northeastern State University, USA
}

\begin{abstract}
This paper examines how the 2008-2009 global economic crisis affected retailers' spending on security and their losses due to theft, burglary, vandalism or arson. The main purpose of the research is to examine whether retailers were successful in allocating their funds to deal with security issues during and after an economic crisis. We investigate the role of firm characteristics, such as size, legal type, gender of owners and top managers, in influencing the level of perceived crime and security spending. Previous literature indicates that shrinkage due to theft, burglary, vandalism or arson is a threat to retailers. Loss due to theft, burglary, vandalism or arson increases in times of economic downturn as overall crime levels go up. We empirically examined the scientific problem, which is relevant to the profitability of retailers, by conducting Wilcoxon tests on data collected from twenty-nine Eastern European and Central Asian countries in 2008 and 2013. The focus of the study was Eastern European and Central Asian countries because Eastern European and Central Asian country governments have less resources to spend on combating crime compared to the developed countries and the impact of global crisis on theft, robbery, vandalism, or arson experienced by retailers might be more accentuated. Our empirical analysis indicated that fewer retailers paid for security after the crisis, and the retailers that paid for security spent less money on security. This is especially true for smaller firms, firms that are not part of a larger firm, sole proprietorships, and firms with no female owner. Fewer shareholding firms spent money on security post-crisis. Fewer retailers with male top managers spent money on security, but the ones that spent money, spent more post-crisis. Fewer retailers experienced losses due to crime post-crisis when compared to the pre-crisis period (except for partnerships, firms with five-to-nineteen employees, and firms with more than ninety-nine employees). Finally, retailers saw crime as less of an obstacle to their operation during the post-crisis period when compared to the pre-crisis period. This research has implications to the policymakers and retail managers by providing them the trends in crime and security spending for different retailer groups.
\end{abstract}

Keywords: crime, retail, retailer, global crisis, economic crisis.

JEL Classification: K42, M31.

Cite as: Balas, A.N., Kaya, H.D. (2019). The Global Economic Crisis And Retailers' Security Concerns: The Trends. SocioEconomic Challenges, 3(2), 5-14.https://doi.org/10.21272/sec.3(2).5-14.2019.

(C) The Authors, 2019. This article is published with open access at Sumy State University.

\section{Introduction}

In this study, we investigate the impact of the 2008-2009 global crisis on retailers' losses due to crime and retailers' spending on security. Our main objective is to see whether retailers were effective in how they spend their budget on security when crime was widespread.

Overall crime levels escalate during economic downturns (Ivaschenko et al., 2012). We assess the role of firm characteristics, such as size, legal type, gender of owners and top managers, in influencing the level of crime during an economic crisis. The main goal of this study is to answer the following research questions: What type of retailers are more influenced by an economic crisis? Do all retailers suffer equally or do some of them suffer more due to theft, burglary, vandalism or arson? Moreover, we investigate to what degree these retailers 
recognize crime as an obstacle. Do retailers generally perceive crime as a bigger obstacle during an economic crisis when compared to other periods? Our objective is to analyze how different types of retailers perceive crime during a crisis period versus a no-crisis period. If crime is more pronounced during a crisis period, firms need to focus more on security. During the crisis period, do more retailers spend money on security? Also, on average, do they spend more money on security during this period? If retailers are successful in distributing their funds, we would observe an increase in the number of firms that spent money on security during the crisis period. We would also find increased dollar spending on security during this period. In summary, our research studies security spending for the whole sample, as well as for different groups of firms differentiated based on size and type.

This current study makes three contributions to the existing literature. First, it examines how a global economic crisis affects the level of crime for retailers. A detailed analysis is conducted by exploring how different types of retailers are affected by a crisis. Second, it investigates how a global economic crisis affects the security spending by retailers in detail by assessing how different type of retailers allocate their funds. Third, it investigates whether different types of retailers are successful in adjusting their security spending based on crime levels. Eastern European and Central Asian countries have less resources to spend on combating crime compared to the developed markets of Western Europe and North America. This is especially true during economic recessions when the governments' tax revenues decrease. It has been reported that Eastern European countries and former Soviet Union have been most affected by the 2008-2009 global economic crisis (Smith and Swain, 2010). We investigate the emerging markets in Eastern Europe and Central Asia as the impact of global crisis on theft, robbery, vandalism, or arson experienced by retailers might be more accentuated due to limited government sources to combat crime.

This research has implications for the policymakers and firm managers by providing them the trends in crime and security spending for different retailer groups based on their characteristics. This research also provides information on whether different retailer groups are successful in adjusting their spending based on the "crime cycle," which closely relates to the "business cycle." The retailers that are found as "unsuccessful" in matching their spending to the actual crime level are advised to make the necessary changes in their policies.

The rest of the paper is organized as follows: In section two, we review literature pertinent to this study. In section three, we describe the data. In section four, empirical results are revealed and the results are discussed. In the final section, we provide conclusions.

\section{Literature review}

Retailing involves the final steps in providing merchandise or services to consumers (Berman et al., 2018; Dunne et al., 2015). One of the major issues retailers deal with is unaccounted merchandise loss due to theft, loss, or damage. The term "shrinkage" or "shortage" is used in the literature (e.g., Beck, 2016; Kohne and Pekeur, 2014) to refer to merchandise that cannot be accounted for (Dunne et al., 2015). Shrinkage is a critical problem for retailers as they operate in a relatively low margin sector (Chapman and Templar, 2006). It has been stated that shrinkage ranges from $1 \%$ to $4 \%$ of retail sales. As most retailers' after-tax profits are a little bit more than $4 \%$ of sales, the level of shrinkage affects the viability of the businesses (Dunne et al., 2015).

Previous literature identified four areas of loss (Bailey and Mishra, 2016; Beck, 2016; Beck. et al., 2006; Chapman and Peacock, 2003; Kohne and Pekeur, 2014). These are internal theft, external theft, inter-company fraud and process failures. This current study focuses on shrinkage caused by internal and external theft.

The first area of loss, internal theft or employee theft, refers to an employee stealing anything of value from the retailer (Mishra and Prasad, 2006). Employee theft is the second major cause of missing inventory. (Beck et al., 2006; Berman et al., 2018; Moraca and Hollinger, 2018). The things that are stolen by the employee include cash, merchandise, property, services and information. Employees can directly steal merchandise from stock rooms and shop floors, scheme with customers and suppliers to steal stock or defraud the retailer, or involve in cashier fraud by stealing money, overcharging, shortchanging, coupon stuffing, giving credits for nonexistent returns, sliding product through the lane without charging, voiding a sale or making a no-sale after a customer has paid (Alstete, 2006; Bailey, 2006; Hayes, 2007; Kohne and Pekeur, 2014; Mishra and Prasad, 2006; Oliphant and Oliphant, 2001). Although retail employee theft can take many forms, the theft of cash and merchandise has the most significant consequence on retailers' profitability (Bailey, 2006). In order to minimize employee theft, retailers can carefully screen applicants prior to hiring by utilizing honesty tests. 
They can also use efficient internal controls such as surveillance systems, random inspections, specialist software; and post signs and charts that track reduction of employee theft (Alstete, 2006; Bailey, 2006; Bamfield, 2006; Mishra and Prasad, 2006). However, such measures add to the costs of doing business (Oliphant and Oliphant, 2001).

The second area of loss, external theft, on the other hand, is commonly known as shoplifting or customer theft, and it is done by a potential customer (Kohne and Pekeur, 2014). Customer theft has been identified as the biggest problem for retailers (Bamfield, 2004). It has been reported that shoplifting accounts for the majority of the overall shrinkage (Beck et al., 2006; Berman et al., 2018; Moraca and Hollinger, 2018). Previous literature divides shoplifters into two groups (Kajalo and Lindblom, 2011). The first group comprise of amateurs whose actions are motivated by a physical or psychological need (Gudjonsson, 1990). These shoplifters maybe adolescents (Cox et al. 1993), stay-at-home mothers (Tonglet 2002), kleptomaniacs (Fullerton, 2007), the homeless, alcoholics and drug addicts (Kajalo and Lindblom, 2011). The second group includes professional shoplifters who steal for a living (Kajalo and Lindblom, 2011; Mohan and Vijayakumar, 2015). Similar to employee theft, customer theft is a threat to retailers' profitability. Although the amount that is spent on security is influenced by the market in which the retailers operate in, it is reported that large amounts are spent on store security and crime prevention worldwide (Kajalo and Lindblom, 2011; Mitchell et al., 2009). The security costs and the cost of inventory lost due to shoplifting result in an increase in cost of doing business and thus increase prices (Kajalo and Lindblom, 2011; Mitchell et al., 2009; Tonglet, 2002).

The third area of loss, inter-company fraud, or vendor fraud, occurs when the suppliers or their agents intentionally deliver fewer goods or lower quality goods than originally agreed (Beck et al., 2006; Haynes, 2007; Kohne \& Pekeur, 2014). Inter-company fraud constitutes poor processes, procedures or controls that allows the vendors to exploit the retailers (Beck et al., 2006). Haynes (2007) mentions two main ways vendor fraud could occur. First, vendor employees may willfully falsify the quantity or quality of shipped goods. Second, delivery persons may shoplift, eat, or wear the goods delivered, or commit fraud by walking the same cases of merchandise more than once, commit invoice fraud by overcharging the retailers, deliver damaged goods with good quality goods, giving less credit for returned merchandise, etc. Although the use of computerized receiving systems would reduce vendor fraud, it is also important to train the employees that receive the merchandise (Haynes, 2007).

Previous literature suggests utilization of RFID (radio frequency identification device) technology to reduce employee, customer and vendor theft (Fan, Chang, Gu, Yi, \& Deng, 2014; Hassan, Sharda \& Kasiri, 2016; Zhou \& Piramuthu, 2017) as RFID allows retailers to precisely oversee their inventory (Lee \& Özer, 2007).

In times of economic downturn, overall crime levels go up (Ivaschenko et al., 2012). One of the reasons for increase in crime levels is lower employment and income levels, especially for property crimes (Lin. 2008; Machin and Meghir, 2004; Raphael and Winter-Ebmer, 2001). Moreover, governments are likely to cut social programs that support the unemployed and underemployed, and this in turn increases the crime rate further (Fajnzylber et al., 2000). In order to combat high crime rates, law enforcement agencies, detention facilities and prisons and crime prevention programs should be improved (Fajnzylber et al., 2000). However, shrinking tax revenue makes it difficult for governments to fulfill these needs. Additionally, to combat with the economic recession, governments might designate their resources on anti-crisis measures rather than measures to combat crime (Ivaschenko et al., 2012).

A high level of crime is perceived as an indication of overall social instability (Ivaschenko et al., 2012), and in times of economic hardship, retailers are faced with an increase in internal and external theft levels (Kajalo and Lindblom, 2011). As stated above, retailers face extra costs, such as loss of goods, hiring of security guards, and installation of security devices to deter theft (Fajnzylber et al., 2000; Kajalo and Lindblom, 2011; Mitchell et al., 2009; Oliphant and Oliphant, 2001; Tonglet, 2002). The reason for implementing the above security measures is to signal to the internal and external thieves that they will be apprehended and arrested if they steal from the retailers (Tonglet, 2002). These security measures will counter the effects of economic hardships that arose from the economic recession (Tonglet, 2002).

In the next section, we describe our sample in detail. In section 3, we will show the results of our analysis. Finally, in section 4, we will provide conclusion. 


\section{Data}

The Business Environment and Enterprise Performance Survey (or BEEPS) is a joint initiative of the World Bank and the European Bank for Reconstruction and Development. It includes 30 countries in Eastern Europe and Central Asia. The countries included in the 2008 and 2013 surveys were Albania, Armenia, Azerbaijan, Belarus, Bosnia and Herzegovina, Bulgaria, Croatia, Czech Republic, Estonia, FYR Macedonia, Georgia, Hungary, Kazakhstan, Kosovo, Kyrgyz Republic, Latvia, Lithuania, Moldova, Mongolia, Montenegro, Poland, Romania, Serbia, Slovak Republic, Slovenia, Tajikistan, Turkey, Ukraine, and Uzbekistan. Russia was only included in the 2013 survey, therefore it is not part of our study.

In order to examine the impact of the 2008-2009 global crisis on retailers' security concerns and security spending, we compare the results of the 2008 survey, which represents the pre-crisis period (as it focuses on fiscal year 2007) to those of the 2013 survey, which represents the post-crisis period. We dropped Russia from our sample as it wasn't included in the 2008 survey. As a result, our sample included 29 countries.

There are four questions that we investigate in this study. The first question is: "In fiscal year 2007, did this establishment pay for security, for example equipment, personnel, or professional security services?" The survey codes "yes" as 1 and "no" as 2 . The second question is: "In fiscal year 2007, what percent of this establishment's total annual sales was paid for security, or what was the total annual cost of security?" The third question is: "In fiscal year 2007, did this establishment experience losses as a result of theft, robbery, vandalism, or arson?" The survey codes "yes" as 1 and "no" as 2 . The fourth and final question is: "Are crime, theft, and disorder No Obstacle, a Minor Obstacle, a Moderate Obstacle, a Major Obstacle, or a Very Severe Obstacle to the current operations of this establishment?" The survey codes "no obstacle" as 0 , "minor obstacle" as 1, "moderate obstacle" as 2, "major obstacle" as 3, and "very severe obstacle" as 4.

Table 1 shows the summary statistics for our sample. While the mean score for the responses to the first question ("In fiscal year 2007, did this establishment pay for security, for example equipment, personnel, or professional security services?") was 1.34 in 2008, it was 1.41 in 2013 (more firms answered "no" in 2013). In other words, the results indicate that fewer retailers spent money on security.

The mean score for the responses to the second question ("In fiscal year 2007, what percent of this establishment's total annual sales was paid for security, or what was the total annual cost of security?") was $4.12 \%$ in 2008, while it was $4.01 \%$ in 2013.

Table 1. Summary Statistics for Retailers

\begin{tabular}{|l|c|c|c|c|c|c|}
\hline & \multicolumn{3}{|c|}{$\mathbf{2 0 0 8}$} & \multicolumn{3}{c|}{$\mathbf{2 0 1 3}$} \\
\hline & $\mathbf{N}$ & Mean & Std & N & Mean & Std \\
\hline Question 1 & 2,532 & 1.34 & 0.47 & 2,866 & 1.41 & 0.49 \\
\hline Question 2 & 745 & 4.12 & 6.44 & 697 & 4.01 & 7.30 \\
\hline Question 3 & 2,527 & 1.73 & 0.44 & 2,858 & 1.78 & 0.41 \\
\hline Question 4 & 2,464 & 1.63 & 1.42 & 2,846 & 0.72 & 1.12 \\
\hline
\end{tabular}

Note 1: For questions 1 and 3, "Yes" is 1 , "No" is 2.

Note 2: For question 4, "No obs." is 0, "Minor" is 1, "Moderate" is 2, "Major" is 3, "Very Severe" is 4.

The mean score for the responses to the third question ("In fiscal year 2007, did this establishment experience losses as a result of theft, robbery, vandalism, or arson?") was 1.73 in 2008, while it was 1.78 in 2013 (more firms answered "no" in 2013, meaning that fewer retailers experienced losses due to crime).

The mean score for the responses to the fourth question ("Are crime, theft, and disorder No Obstacle, a Minor Obstacle, a Moderate Obstacle, a Major Obstacle, or a Very Severe Obstacle to the current operations of this establishment?") was 1.63 in 2008, while it was 0.72 in 2013. In other words, retailers saw crime as less of an obstacle in 2013.

In the following section, we compare the 2008 survey results to the 2013 survey results using the MannWhitney-Wilcoxon tests. First, we compare the results in 2008 to the results in 2013 for all retailers and then we do the same for all wholesalers. Then, we do comparisons for each subgroup using the Mann-WhitneyWilcoxon tests. 


\section{Empirical results}

Table 2 compares pre- and post-crisis responses given to the following question: "In fiscal year 2007, did this establishment pay for security, for example equipment, personnel, or professional security services?" We report the means for the 2008 and the 2013 survey responses. We also show the p-values for the Mann-WhitneyWilcoxon tests that compare the 2008 responses to the 2013 responses.

For all firms, the mean value of the responses in 2008 is 1.34, while it is 1.41 in 2013 . The difference between the responses in the pre- and post-crisis periods is statistically significant $(p<0.0001)$. "Yes" is coded as 1 and "no" is coded as 2, therefore a higher score in 2013 (when compared to 2008) indicates that fewer retailers paid for security in the post-crisis period when compared to the pre-crisis period.

Table 2. Did the Retailer Pay for Security during Last Year?

\begin{tabular}{|c|c|c|c|}
\hline \multicolumn{4}{|c|}{ Wilcoxon test } \\
\hline & 2008 & 2013 & P-value \\
\hline All & 1.34 & 1.41 & $<0.0001$ \\
\hline Employees5-19 & 1.42 & 1.46 & 0.0065 \\
\hline Employees20-99 & 1.27 & 1.34 & 0.0011 \\
\hline Employees $>99$ & 1.21 & 1.22 & 0.3719 \\
\hline Part of a larger firm & 1.26 & 1.31 & 0.1164 \\
\hline Not part of a larger firm & 1.35 & 1.42 & $<0.0001$ \\
\hline Shareholding firm trading in the stock market & 1.32 & 1.50 & 0.0100 \\
\hline Shareholding firm shares traded privately & 1.29 & 1.40 & $<0.0001$ \\
\hline Sole proprietorship & 1.42 & 1.47 & 0.0733 \\
\hline Partnership & 1.45 & 1.42 & 0.3349 \\
\hline Limited partnership & 1.47 & 1.47 & 0.4673 \\
\hline Other & 1.25 & 1.44 & 0.0031 \\
\hline One or more female owner & 1.37 & 1.36 & 0.4053 \\
\hline No female owner & 1.31 & 1.44 & $<0.0001$ \\
\hline Top manager female & 1.37 & 1.37 & 0.4699 \\
\hline Top manager not female & 1.32 & 1.43 & $<0.0001$ \\
\hline Firm without an intl recog. Quality certification & 1.35 & 1.42 & $<0.0001$ \\
\hline Firm with an intl recog. Quality certification & 1.24 & 1.35 & 0.0003 \\
\hline
\end{tabular}

Note: yes is 1 , no is 2 .

When we examine different firm size groups, we observe that after the crisis, fewer retailers with five-tonineteen employees or with twenty-to-ninety nine employees spent money on security. On the other hand, we do not observe the same for larger retailers (i.e. retailers with more than ninety nine employees). The difference between pre- and post-crisis is not statistically significant for this group $(\mathrm{p}=0.3719)$.

When we differentiate retailers based on whether they were a part of a larger firm or not, we are seeing that fewer firms that are not part of a larger firm paid for security after the crisis $(\mathrm{p}<0.0001)$. On the other hand, we cannot say the same for retailers that are part of a larger firm. The difference between pre-and post-crisis is not statistically significant for this group $(\mathrm{p}=0.1164)$.

When we compare retailers with respect to legal status (shareholding firm with shares trading in the market, shareholding firm with shares traded privately, sole proprietorship, partnership, etc.), the results indicate that fewer shareholding firms, fewer sole proprietorships and fewer "other" type of retailers spent money on security. However, the difference between pre- and post-crisis is not statistically significant for partnerships $(\mathrm{p}=0.3349)$ or for limited partnerships $(\mathrm{p}=0.4673)$.

When we investigate retailers with respect to the gender of their owners, we find fewer firms with all male owners (i.e. "no female owner") spent money on security post-crisis when compared to pre-crisis $(\mathrm{p}<0.0001)$. However, we do not see a significant difference for firms with one or more female owner between pre- and post-crisis $(\mathrm{p}=0.4053)$. 
When we differentiate the firms with respect to the gender of their top manager, we are seeing that fewer firms with a male top manager (i.e. top manager not female) spent money on security after the crisis $(\mathrm{p}=0.0112)$. On the other hand, we do not see a significant difference for firms with a female top manager between preand post-crisis $(\mathrm{p}=0.4699)$.

Finally, when we differentiate the firms with respect to their holding of an internationally recognized quality certification (i.e. ISO 9000, 9002, 14000, etc.), we are seeing that fewer retailers in both groups paid for security after the crisis. Therefore, it does not matter whether the retailer has a certification or not.

Table 3 demonstrates the results of the responses given to the question: "In fiscal year 2007, what percent of this establishment's total annual sales was paid for security, or what was the total annual cost of security?"

The results indicate that the mean value of the responses in 2008 was $4.12 \%$ of sales, while it is $4.01 \%$ of sales in 2013 for the entire sample. The difference between the responses in the pre- and post-crisis periods is statistically significant $(\mathrm{p}=0.0073)$. The retailers spent less money for security post-crisis.

When we examine the subgroups, we are seeing that the difference in pre- and post-crisis is not statistically significant for some subgroups. These subgroups are retailers with twenty-to-ninety-nine employees, retailers with more than ninety-nine employees, firms that are part of a larger firm, shareholding firms, partnerships, limited partnerships, and firms with one or more female owner. Therefore, we can say that the results for certain groups of firms (i.e. small firms, sole proprietorships, etc.) drive the overall results.

The results of our study illustrate that the retailers that have a male top manager actually spent more money for security post-crisis ( $4.10 \%$ of sales in 2008 versus $4.26 \%$ of sales in $2013 ; \mathrm{p}=0.0225$ ). This finding is in contrast to the result for the whole sample.

Table 3. Retailer's Percentage of Annual Sales Paid for Security

\begin{tabular}{|l|c|c|c|}
\hline \multicolumn{2}{|c|}{ Wilcoxon test } & \multicolumn{2}{l|}{} \\
\hline & $\mathbf{2 0 0 8}$ & $\mathbf{2 0 1 3}$ & P-value \\
\hline All & 4.12 & 4.01 & 0.0073 \\
\hline Employees5-19 & 4.61 & 3.82 & 0.0032 \\
\hline Employees20-99 & 3.81 & 3.66 & 0.1225 \\
\hline Employees>99 & 3.58 & 3.66 & 0.2971 \\
\hline Part of a larger firm & 4.44 & 3.73 & 0.4464 \\
\hline Not part of a larger firm & 4.08 & 4.05 & 0.0056 \\
\hline Shareholding firm trading in the stock market & 3.68 & 3.00 & 0.3322 \\
\hline Shareholding firm shares traded privately & 3.65 & 4.21 & 0.2546 \\
\hline Sole proprietorship & 5.70 & 2.96 & 0.0101 \\
\hline Partnership & 4.28 & 4.40 & 0.4805 \\
\hline Limited partnership & 4.40 & 3.20 & 0.1920 \\
\hline Other & 4.06 & 2.92 & 0.0738 \\
\hline One or more female owner & 3.69 & 4.27 & 0.2071 \\
\hline No female owner & 4.48 & 3.84 & $<0.0001$ \\
\hline Top manager female & 4.20 & 3.43 & 0.1157 \\
\hline Top manager not female & 4.10 & 4.26 & 0.0225 \\
\hline Firm without an intl recog. Quality certification & 4.03 & 4.00 & 0.0091 \\
\hline Firm with an intl recog. Quality certification & 4.55 & 3.41 & 0.0695 \\
\hline
\end{tabular}

Table 4 illustrates the retailers' losses due to theft, robbery, vandalism, or arson pre- and post-crisis. It shows the responses given to the following question: "In fiscal year 2007, did this establishment experience losses as a result of theft, robbery, vandalism, or arson?" The survey codes "yes" as 1 and "no" as 2 . The results indicate that fewer firms experienced losses due to crime post-crisis when compared to pre-crisis. The mean value is 1.73 in 2008 versus 1.78 in 2013 ( $\mathrm{p}<0.0001)$.

When we look into the subgroups, we are seeing that in most subgroups (except for retailers with 5-19 employees, retailers with more than 99 employees, partnerships, and limited partnerships) there were fewer firms experiencing losses due to crime post-crisis. 
Table 4. Any Losses due to Theft, Robbery, Vandalism, or Arson?

\begin{tabular}{|l|c|c|c|}
\hline \multicolumn{2}{|c|}{ Wilcoxon Test } & \multicolumn{3}{l|}{} \\
\hline & $\mathbf{2 0 0 8}$ & $\mathbf{2 0 1 3}$ & P-value \\
\hline All & 1.73 & 1.78 & $<0.0001$ \\
\hline Employees5-19 & 1.82 & 1.82 & 0.3897 \\
\hline Employees20-99 & 1.69 & 1.75 & 0.0024 \\
\hline Employees>99 & 1.56 & 1.61 & 0.1366 \\
\hline Part of a larger firm & 1.63 & 1.77 & 0.0001 \\
\hline Not part of a larger firm & 1.74 & 1.79 & 0.0005 \\
\hline Shareholding firm trading in the stock market & 1.70 & 1.83 & 0.0337 \\
\hline Shareholding firm shares traded privately & 1.70 & 1.78 & $<0.0001$ \\
\hline Sole proprietorship & 1.81 & 1.76 & 0.0546 \\
\hline Partnership & 1.73 & 1.78 & 0.2386 \\
\hline Limited partnership & 1.86 & 1.92 & 0.1576 \\
\hline Other & 1.62 & 1.79 & 0.0059 \\
\hline One or more female owner & 1.71 & 1.79 & $<0.0001$ \\
\hline No female owner & 1.75 & 1.78 & 0.0254 \\
\hline Top manager female & 1.70 & 1.77 & 0.0006 \\
\hline Top manager not female & 1.74 & 1.79 & 0.0006 \\
\hline Firm without an intl recog. Quality certification & 1.74 & 1.78 & 0.0007 \\
\hline Firm with an intl recog. Quality certification & 1.72 & 1.81 & 0.0011 \\
\hline
\end{tabular}

Note: "Yes" is 1, "No" is 2.

Table 5 compares the pre- and post-crisis responses given to the following question: "Are crime, theft, and disorder No Obstacle, a Minor Obstacle, a Moderate Obstacle, a Major Obstacle, or a Very Severe Obstacle to the current operations of this establishment?". The survey codes "no obstacle" as 0 , "minor obstacle" as 1 , "moderate obstacle" as 2, "major obstacle" as 3, and "very severe obstacle" as 4.

The table demonstrates that the retailers saw crime as less of an obstacle after the crisis. The mean value for all firms is 1.63 in 2008, while it is 0.72 in 2013 ( $\mathrm{p}<0.0001$ ). In other words, in the earlier survey, the average respondent saw crime as a "Minor" to "Moderate" obstacle for their business. In the later survey, these issues were seen as almost no obstacle to the firms' operations. The table shows that, for all firm size groups and firm types, this finding is valid.

Table 5. Are Crime, Theft, and Disorder an Obstacle for the Retailer?

\begin{tabular}{|l|c|c|c|}
\hline \multicolumn{2}{|c|}{ Wilcoxon Test } & \multicolumn{2}{l|}{} \\
\hline & $\mathbf{2 0 0 8}$ & $\mathbf{2 0 1 3}$ & P-value \\
\hline All & 1.63 & 0.72 & $<0.0001$ \\
\hline Employees5-19 & 1.56 & 0.67 & $<0.0001$ \\
\hline Employees20-99 & 1.67 & 0.78 & $<0.0001$ \\
\hline Employees $>99$ & 1.73 & 0.87 & $<0.0001$ \\
\hline Part of a larger firm & 1.72 & 0.75 & $<0.0001$ \\
\hline Not part of a larger firm & 1.61 & 0.72 & $<0.0001$ \\
\hline Shareholding firm trading in the stock market & 1.78 & 0.31 & $<0.0001$ \\
\hline Shareholding firm shares traded privately & 1.58 & 0.73 & $<0.0001$ \\
\hline Sole proprietorship & 1.73 & 0.72 & $<0.0001$ \\
\hline Partnership & 1.68 & 0.84 & $<0.0001$ \\
\hline Limited partnership & 1.53 & 0.59 & 0.0001 \\
\hline Other & 1.57 & 0.73 & $<0.0001$ \\
\hline One or more female owner & 1.71 & 0.77 & $<0.0001$ \\
\hline No female owner & 1.56 & 0.68 & $<0.0001$ \\
\hline Top manager female & 1.76 & 0.83 & $<0.0001$ \\
\hline
\end{tabular}


Table 5 (cont.). Are Crime, Theft, and Disorder an Obstacle for the Retailer?

\begin{tabular}{|c|c|c|c|}
\hline \multicolumn{4}{|c|}{ Wilcoxon Test } \\
\hline & 2008 & 2013 & P-value \\
\hline Top manager not female & 1.57 & 0.68 & $<0.0001$ \\
\hline Firm without an intl recog. Quality certification & 1.66 & 0.72 & $<0.0001$ \\
\hline Firm with an intl recog. Quality certification & 1.43 & 0.66 & $<0.0001$ \\
\hline
\end{tabular}

Note: "No obs." is 0, "Minor" is 1, "Moderate" is 2, "Major" is 3, "Very Severe" is 4.

\section{Conclusion}

In this study, we examine the impact of the 2008-2009 global crisis on retailers' security spending. We also investigate the impact of the crisis on their losses due to crime. Findings of the study show that, overall, fewer retailers paid for security after the crisis ended. This result is especially true for smaller retailers (retailers less than one hundred employees), firms that are not part of a larger firm, sole proprietorships and shareholding firms, firms with no female owner, and firms that have a male top manager. Further research is needed to determine the reason for this finding.

Furthermore, the results indicate that retailers that spent money on security spent less after the crisis. This result is supported by the previous literature that argues that retailers' security costs would increase during economic downturn (Fajnzylber et al. 2000). The smallest retailers (retailers with less than twenty employees) reduced their spending significantly after the crisis passed. This may be due to smaller retailers not having financial means to continue their spending on security. The results did not indicate any significant changes in the money spent in retailers that have more than twenty employees. In addition, retailers that are not part of a larger firm reduced their spending after the crisis. This might also be due to the limited financial resources of such firms. In times of economic recovery, there is less need for security spending, especially for firms with limited resources. The results did not support any significant change for firms that are part of larger firms. Firms that are part of larger firms are likely to have more financial resources than stand-alone retailers. Moreover, our results revealed that retailers that are sole proprietorships reduced their security spending significantly after crisis. This again might be due to these retailers having limited financial resources. On the other hand, retailers that were partnerships and shareholding firms did not reduce their security spending after the crisis.

With respect to the impact of gender on security spending, we find that firms with no female owner spent significantly less on security after the crisis passed. However, our results show that firms with a male top manager spent more on security after the crisis ended. Firms with a male top manager seem to behave differently when compared to firms with a female top manager or when compared to the general population of firms. During the crisis, the firms with a male top manager spent less on security when compared to the firms with a female top manager. On the other hand, after the crisis ended, retailers with a male top manager spent more on security when compared to the firms with a female top manager. Further research is needed to reveal the reason behind this finding.

he results of our study revealed that, after the crisis, fewer firms reported losses due to crime. This result is in line with previous research that reported a relationship between crime in retailers and economic conditions (Ivaschenko et al. 2012). This finding is valid for most types of firms (i.e. except for the smallest firms, the largest firms, and the partnerships). However, for sole proprietorships, we find a different trend. More of the sole proprietorships experienced losses due to crime after the crisis ended.

In the final section, we examine whether the respondents saw crime as an obstacle. Our results show that firms saw crime as less of an obstacle after the crisis ended. This finding is valid for all firm types. While before the crisis the average respondent was seeing crime as a minor to moderate obstacle for their retailer, after the crisis ended these issues were seen as almost no obstacle.

These findings will guide retailers with respect to their security spending. Our results show that during the crisis when crime was more rampant, more retailers spent money on security and a higher percentage of firms spent money on security. This shows that retailers were generally successful in terms of taking more precautions when crime was more rampant. On the other hand, our results indicate that retailers with a male top 
manager were not as successful. After the crisis ended, although fewer of them, on average, experienced losses due to crime, the ones that spent money spent more when compared to the earlier period.

The results for sole proprietorships are also interesting. The crime and security spending trends for these retailers are different from other firms. More of these retailers experienced losses after the crisis ended. However, fewer of them spent money on security after the crisis ended. Also, the ones that spent money on security, they spent a lower amount post-crisis. Therefore, we can conclude that they were not successful in allocating their funds.

We conclude that although an economic crisis may cause crime rates to go up initially, over time, this trend reverses. Therefore, retailers need to recognize this cycle in crime rates surrounding economic crises and adjust their security spending accordingly. Overall, we advise both sole proprietorships and retailers with a male top manager to be more careful in allocating their money for security spending. They should increase their spending in periods when theft goes up, not the opposite.

\section{References}

1. Alstete, J. (2006). Inside advice on educating managers for preventing employee theft. International Journal of Retail and Distribution Management, 34(11), 833-844. https://doi.org/10.1108/09590550610710237.

2. Bailey, A.A. (2006). Retail employee theft: a theory of planned behavior perspective. International Journal of Retail and Distribution Management, 34(11), 802-816. https://doi.org/10.1108/09590550610710219.

3. Bailey, A.A., \& Mishra, A. (2016). Internal marketing, retail employee commitment, and employee response to retail theft: An Exploration. In M. W. Obal, N. Krey, and C. Bushardt (Eds.), Let's Get Engaged! Crossing the Threshold of Marketing's Engagement Era (833-838). Springer International Publishing.

4. Bamfield, J. (2004). Shrinkage, shoplifting and the cost of retail crime in Europe: a cross-sectional analysis of major retailers in 16 European countries. International Journal of Retail and Distribution Management, 32(5), 235-241. https://doi.org/10.1108/09590550410699233.

5. Bamfield, J. (2006). Sed quis custodiet? Employee theft in UK retailing. International Journal of Retail and Distribution Management, 34(11), 845-859. https://doi.org/10.1108/09590550610710246.

6. Berman, B., Evans, J. R., \& Chatterjee, P. (2018). Retail management - A strategic approach. $13^{\text {th }}$ eds. Pearson.

7. Beck, A. (2016). Beyond shrinkage: Introducing total retail loss. Technical report by RILA (Retail Industry Leaders Association). [pdf] Available at < http://www.rila.org/protection/resources/BeyondShrinkageReport/Documents/RILA\%2060\%20Second\%20Guide\%20to\%20Total\%20Retail\%20Loss.pdf> [Accessed 16 December 2018].

8. Beck, A., Chapman, P., \& Peacock, C. (2003). Shrinkage: A collaborative approach to reducing stock loss in the supply chain. ECR Europe, Brussels. [pdf] Available at: < https://www.ecr.digital/wp_contents/uploads/2016/09/ECR-Bericht_Shrinkage.pdf > [Accessed 16 December 2018].

9. Chapman, P., \& Templar, S. (2006). Scoping the contextual issues that influence shrinkage measurement. International Journal of Retail and Distribution Management, 34(11), 860-972.

10. Cox, A.D., Cox, D., Anderson, R.D., \& Moschis, G P. (1993). Research note: Social influences on adolescent shoplifting - Theory, evidence, and implications for the retail industry. Journal of Retailing, 69(2), 234-246.

11. Dunne, P.M., Lusch, R.F., \& Carver, J.R. (2014). Retailing. $8^{\text {th }}$ eds. South-Western Cengage Learning.

12. Fajnzylber, P., Lederman, D., Loayza, N., Reuter, P., Roman, J., \& Gaviria, A. (2000). Crime and victimization: An economic perspective. Economía, 1(1), 219-302.

13. Fan, T.-J., Chang, X.-Y., Gu, C.-H., Yi, J.-J., \& Deng, S. (2014). Benefits of RFID technology for reducing inventory shrinkage. International Journal of Production Economics, 147, 659-665. https://doi.org/10.1016/j.ijpe.2013.05.007.

14. Fullerton, R. A. (2007). Psychoanalyzing kleptomania. Marketing Theory, 7(4), 335-352. https://doi.org/10.1177/1470593107083160.

15. Gudjonsson, G. (1990). Psychological and psychiatric aspects of shoplifting. Medicine, Science and Law, $30(1), 45-51$. 
16. Hassan Zadeh, A., Sharda, R., \& Kasiri, N. (2016). Inventory record inaccuracy due to theft in productioninventory systems. International Journal of Advanced Manufacturing Technology, 83(1-4), 623-631. https://doi.org/10.1007/s00170-015-7433-3.

17. Hayes, R. (2007). Vendor theft and error. In R. Hayes (Ed.), Retail Security and Loss Prevention (pp. 2528). https://doi.org/10.1057/9780230598546_3.

18. Ivaschenko, O., Nivorozhkin, A., \& Nivorozhkin, E. (2012). The role of economic crisis and social spending in explaining crime in Russia: Regional panel data analysis. Eastern European Economics. 50, 21-41.

19. Kajalo, S., \& Lindblom, A. (2011). An empirical analysis of retail entrepreneurs' approaches to prevent shoplifting. Security Journal, 24(4), 269-282. https://doi.org/10.1057/sj.2010.3.

20. Kohne, C., \& Pekeur, S. W. (2014). An assessment to determine the impact of retail shrinkage on the sustainability and the profitability of XYC franchise retail stores in the Westerns Cape region of South Africa. Arabian Journal of Business and Management Review, 3(11), 101-117.

21. Lee, H., \& Özer, Ö. (2007). Unlocking the value of RFID. Production and Operations Management; Muncie, 16(1), 40-64.

22. Lin, M.-J. (2008). Does unemployment increase crime? Evidence from U.S. data 1974-2000. The Journal of Human Resources, 43(2), 413-436.

23. Machin, S., \& Meghir C. (2004). Crime and economic incentives. Journal of Human Resources, 39(4), 958-979.

24. Mohan, N.D., \& Vijayakumar, J. (2015). Fighting retail shrinkage through intelligent analysis and validation. White Paper by Infosys. [pdf] Available at: <https://pdfs.semanticscholar.org/bf7b/2d80ac6c343e6baf3be7a826701ba80b12c1.pdf > [Accessed 16 December 2018].

25. Mitchell, V.W., Balabanis, G., Schlegelmilch, B.B., \& Cornwell, T.B. (2009). Measuring unethical consumer behavior across four countries. Journal of Business Ethics, 88(2), 395-412. https://doi.org/10.1007/s10551-008-9971-1.

26. Moraca, B., \& Hollinger, R. (2018). 2018 National Retail Security Survey. https://cdn.nrf.com/sites/default/files/2018-10/NRF-NRSS-Industry-Research-Survey-2018.pdf [Accessed 16 December 2018].

27. Oliphant, B.J., \& Oliphant, G.C. (2001). Using a behavior-based method to identify and reduce employee theft. International Journal of Retail \& Distribution Management, 29(10), 442-451.

28. Prasad, A., \& Mishra, B. K. (2006). Minimizing retail shrinkage due to employee theft. International Journal of Retail \& Distribution Management, 34(11), 817-832. https://doi.org/10.1108/09590550610710228.

29. Raphael, S., \& Winter-Ebmer, R. (2001). Identifying the effect of unemployment on crime. Journal of Law and Economics, 259-283.

30. Smith, A., \& Swain, A. (2010). The global economic crisis, Eastern Europe, and the former Soviet Union: Models of development and the contradictions of internationalization. Eurasian Geography and Economics, 51(1), 1-34. https://doi.org/10.2747/1539-7216.51.1.1.

31. Tonglet, M. (2002). Consumer misbehaviour: an exploratory study of shoplifting. Journal of Consumer Behaviour, 1(4), 336-354. https://doi.org/10.1002/cb.79

32. Zhou, W., \& Piramuthu, S. (2017). Identification shrinkage in inventory management: an RFID-based solution. Annals of Operations Research, 258(2), 285-300. https://doi.org/10.1007/s10479-015-2022-2. 